\title{
International Journal of Transpersonal Studies
}

Volume 30

Iss. 1-2 (2011)

Article 12

$1-1-2011$

\section{Reflections on the Need for a More Complete History of The Deep Ecology Movement and Related Disciplines}

\author{
Michael E. Zimmerman \\ University of Colorado
}

Follow this and additional works at: https://digitalcommons.ciis.edu/ijts-transpersonalstudies

Part of the Philosophy Commons, Psychology Commons, and the Religion Commons

\section{Recommended Citation}

Zimmerman, M. E. (2011). Zimmerman, M. E. (2011). Reflections on the need for a more complete history of the deep ecology movement and related disciplines. International Journal of Transpersonal Studies, 30(1-2), 118-119.. International Journal of Transpersonal Studies, 30 (1). http://dx.doi.org/10.24972/ ijts.2011.30.1-2.118

\section{(i) $9 \Theta$}

This work is licensed under a Creative Commons Attribution-Noncommercial-No Derivative Works 4.0 License. This Special Topic Article is brought to you for free and open access by International Journal of Transpersonal Studies. It has been accepted for inclusion in International Journal of Transpersonal Studies by an authorized administrator. For more information, please contact the editors. 


\title{
RESPONSE:
}

\section{Reflections on the Need for a More Complete History of The Deep Ecology Movement and Related Disciplines}

\author{
Michael E. Zimmerman \\ University of Colorado \\ Boulder, CO, USA
}

A lan Drengson and the late Bill Devall have written an interesting article with Mark A. Schroll about the Deep Ecology Movement. Their article discusses some of the movement's history, but focuses primarily on its major tenets, such as the Deep Ecology Platform, and on how Deep Ecology meshes with other contemporary concerns, especially social justice.

Despite these merits, the article omits a lot of the movement's history, especially its feisty antianthropocentrism and its opposition to Green social justice issues that a number of deep ecologists displayed during at least the first two decades of the movement. Perhaps the key American Deep Ecologist is George Sessions, whom I met in 1976 when I was presenting an eco-philosophy paper at the American Philosophical Association Meeting in Berkeley, California. We both rejoiced to discover another philosopher with similar interests. For more than 20 years, Sessions and I corresponded, worked together, and spent time together on camping trips, with the aim of articulating various aspects of Deep Ecology. An indication of my respect for Sessions' work is that I invited him to edit the Deep Ecology section of my anthology, Environmental Philosophy: From Animal Rights to Radical Environmentalism. A senior editor at Prentice Hall was puzzled by the proposal, which included a section on Ecofeminism as well, but ultimately he agreed to publish the anthology, with Sessions editing his section of the first three editions.

A tireless promoter of the Deep Ecology Movement, Sessions was also a fierce critic of anthropocentrism, as were Devall and I at the time. The idea of biocentric egalitarianism was a constructive expression of anti-anthropocentrism, although as Drengson and Devall point out, many Deep Ecologists moved away from this perspective, with the possible exception of Sessions and some others.
In August 1981, Sessions, Devall, Steve Meyers, and I accepted the invitation of the late Deep Ecologist Dolores LaChapelle to take part in a "Heidegger in the Mountains" symposium at her home in Silverton, Colorado. This symposium revealed tensions at play between my Heideggerian form of anti-anthropocentrism and the anti-anthropocentrism favored by Sessions and Devall. Eventually, my concerns about the philosophical dimension of Heidegger's involvement with National Socialism led me to urge Deep Ecologists to explore whether their frequent expressions of anti-modernism could lead to support for a version of eco-fascism. I concluded that Heidegger should not be promoted as a forerunner of Deep Ecology. This fact may help to explain why Sessions chose not to include any of my publications on Deep Ecology in his anthology, Deep Ecology for the 21: Century.

Despite the importance of Sessions' views and contributions to the Deep Ecology movement, the article under consideration makes scant reference to him, a fact that may stem in part from the falling out that occurred between Devall and Sessions many years ago. Another reason for downplaying Sessions' contributions is that doing so would have made the historical overview of Deep Ecology much less politically correct. In effect, the history offered here bowdlerizes the Deep Ecology Movement, perhaps to make it appear more acceptable to other environmental movements, including Ecofeminism and the Green Movement. In fact, however, several leading Deep Ecologists were at odds with these movements. Although in the mid-1980s I wrote articles trying to discover common ground between Deep Ecology and Ecofeminism, many ecofeminists regarded Deep Ecology as hopelessly androcentric and incapable of understanding how misogyny has contributed to ecological problems. Sessions and Devall were not exactly light on their feet in regard to this conflict. 
Something similar is true as well in regard to the Deep Ecology-social justice relationship. Although the current article depicts this relationship as healthy, almost to the point that Deep Ecology is depicted as equivalent to the social justice movement(s), Deep Ecologists such as Sessions, Devall, and Arne Naess insisted for many years that Deep Ecology was primarily concerned not with social justice, but rather with wilderness protection. This stance helps to explain why so many Earth First!ers adopted some version of Deep Ecology.

About twenty years ago, I was invited to be a panelist at the "Human in Nature" conference at what is now Naropa University in Boulder, Colorado. Alan Drengson and Bill Devall were panelists as well. I distinctly recall Bill Devall taking a position about social justice issues and Deep Ecology that dismayed many people in the room, a position that seemed incapable of being reconciled with his background as a sociologist. People change, fortunately, and Devall-as evidenced by the present article-evolved to hold a much more constructive view of the Deep Ecology-social justice relationship. The complete history of the Deep Ecology Movement remains to be written. 